\title{
Hereditary haemorrhagic telangiectasia with extensive liver involvement is not caused by either HHT1 or HHT2
}

\author{
M Piantanida, E Buscarini, C Dellavecchia, A Minelli, A Rossi, L Buscarini, \\ C Danesino
}

Biologia Generale e Genetica Medica,

Università di Pavia, CP 217, 27100 Pavia,

Italy

C Danesino

C Dellavecchia

A Minelli

M Piantanida

Divisione di

Gastroenterologia,

Ospedale di Piacenza,

Italy

E Buscarini

L Buscarini

Servizio di

Immunoematologia

Ospedale di Piacenza,

Italy

A Rossi

Correspondence to:

Dr Danesino.

Received 1 February 1996

Accepted for publication

1 March 1996

\begin{abstract}
Hereditary haemorrhagic telangiectasia (HHT) is a genetically heterogeneous dominant disorder. Two disease loci have been mapped to chromosomes $9 \mathrm{q} 3$ and 12q. In a large pedigree, with an unusually high number of patients with liver vascular malformations, both previously mapped loci have been excluded. The loci for two other inherited vascular malformation diseases, cerebral cavernous malformations and multiple cutaneous and mucosal venous malformations, have also been excluded. Thus we conclude that at least a third, as yet unmapped, HHT locus does exist, possibly associated with high frequency of liver involvement.

( $($ Med Genet 1996;33:441-443)
\end{abstract}

Key words: HHT; Rendu-Osler-Weber; genetic heterogeneity; liver involvement.

Hereditary haemorrhagic telangiectasia, also known as Rendu-Osler-Weber disease, is a well known, although rare, autosomal dominant disorder. Telangiectases formed by dilated capil- lary vessels on skin and mucosa usually cause nasal and gastrointestinal bleeding. Other angiodysplastic lesions include arteriovenous malformations and angiomas. Although commonest in the pulmonary circulation, arteriovenous shunts can potentially affect every organ, and cause gastrointestinal haemorrhage, hepatic fibrosis, hyperdynamic circulation, and neurological symptoms owing to emboli or cerebral vascular malformations. ${ }^{1}$

A disease locus, HHT1, was assigned by linkage analysis to chromosome $9 \mathrm{q} 34 .{ }^{23}$ After further refinement of the positional mapping, a candidate gene approach succeeded in identifying mutations in the gene coding for endoglin, a membrane glycoprotein binding transforming growth factor beta (TGF- $\beta$ ), expressed at high levels in endothelial cells. ${ }^{4}$ Genetic heterogeneity of HHT has been reported, ${ }^{4-7}$ possibly reflecting heterogeneity of clinical manifestations.

A second locus, HHT2, was recently assigned to chromosome $12 \mathrm{q}^{8}{ }^{8}$ One family was reported to be linked to markers of chromosome $3 \mathrm{p} 22,{ }^{4}$ in a region in which the gene for TGF- $\beta$ receptor type II had been mapped, but

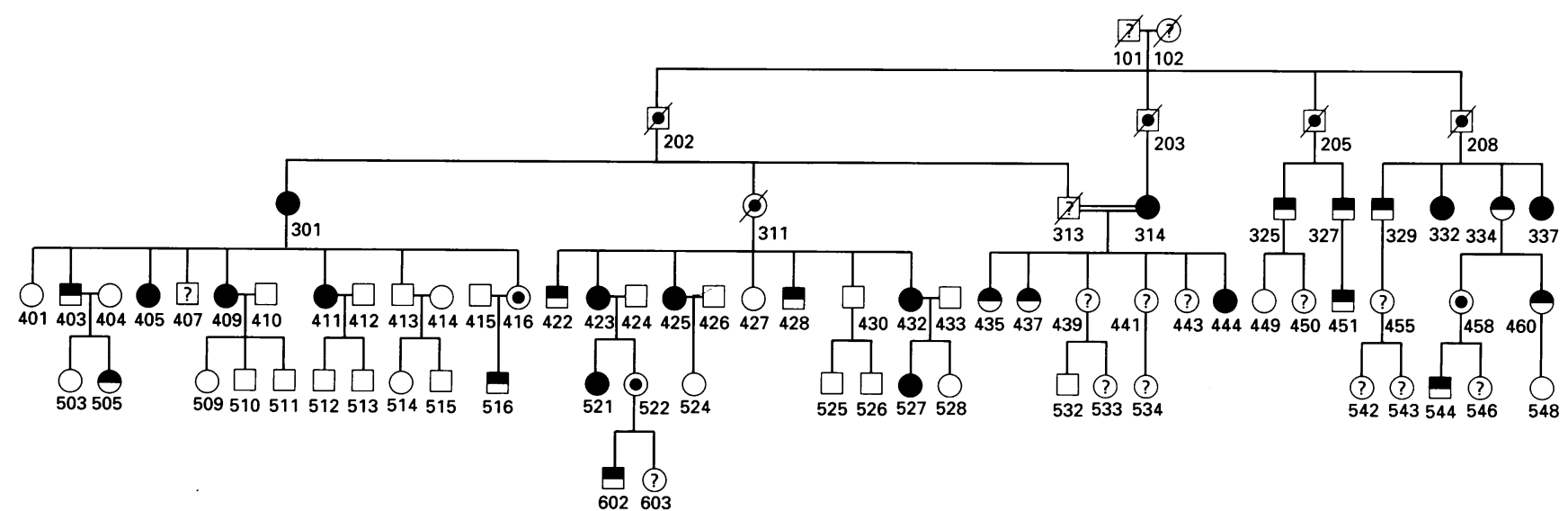

Affected with liver involvement

$\square$ Obligate carrier without signs or history Affected with telangiectases/epistaxis

?? Affection status uncertain 
further studies on the same family resulted in stronger evidence of linkage with chromosome 12 markers. ${ }^{9}$ At present no families have been reported for which both HHT1 and HHT2 have been excluded. ${ }^{10}$

Loci for cerebral cavernous malformations (CCM1) and multiple cutaneous and mucosal venous malformations (VMCM) were assigned by linkage analysis to chromosomes 7q11$\mathrm{q} 21^{11-13}$ and $9 \mathrm{p}^{1415}$ respectively. Both are autosomal dominant disorders with some features resembling $\mathrm{HHT}$.

\section{Methods}

FAMILY DESCRIPTION

We studied a large HHT family with 30 affected subjects (fig 1). In 13 female patients we documented angiodysplastic liver involvement. ${ }^{16}$ In two male patients, in addition to telangiectases, we found anomalies of the splenic artery (fig
1 , No 544) and nodular steatosis of the liver (fig 1, No 428).

In one patient the hepatic arteriovenous malformations caused symptomatic hyperdynamic circulation which was successfully treated by embolisation of hepatic artery branches.

POLYMORPHISM TYPING AND LINKAGE ANALYSIS Genomic DNA extraction from samples of citrated venous blood and $A B O$ blood group typing were performed by routine techniques.

The short tandem repeat polymorphisms were typed by PCR amplification in an $8 \mu \mathrm{l}$ reaction volume containing 20 to $100 \mu \mathrm{g}$ of genomic DNA as template, $330 \mathrm{nmol} / 1$ each primer, $200 \mu \mathrm{mol} / 1$ each dCTP, dGTP, and dTTP, $25 \mu \mathrm{mol} / 1$ dATP, $1 \mu \mathrm{Ci}\left[\alpha^{35} \mathrm{~S}\right] \mathrm{dATP}$, $50 \mathrm{mmol} / 1 \mathrm{KCl}, 10 \mathrm{mmol} / 1$ Tris, $1.5 \mathrm{mmol} / 1$ $\mathrm{MgCl}_{2}, 0 \cdot 1 \%$ Triton X-100, $0.01 \%$ gelatine, and $0 \cdot 2 \mathrm{U} \mathrm{Taq}$ polymerase. Samples were over-
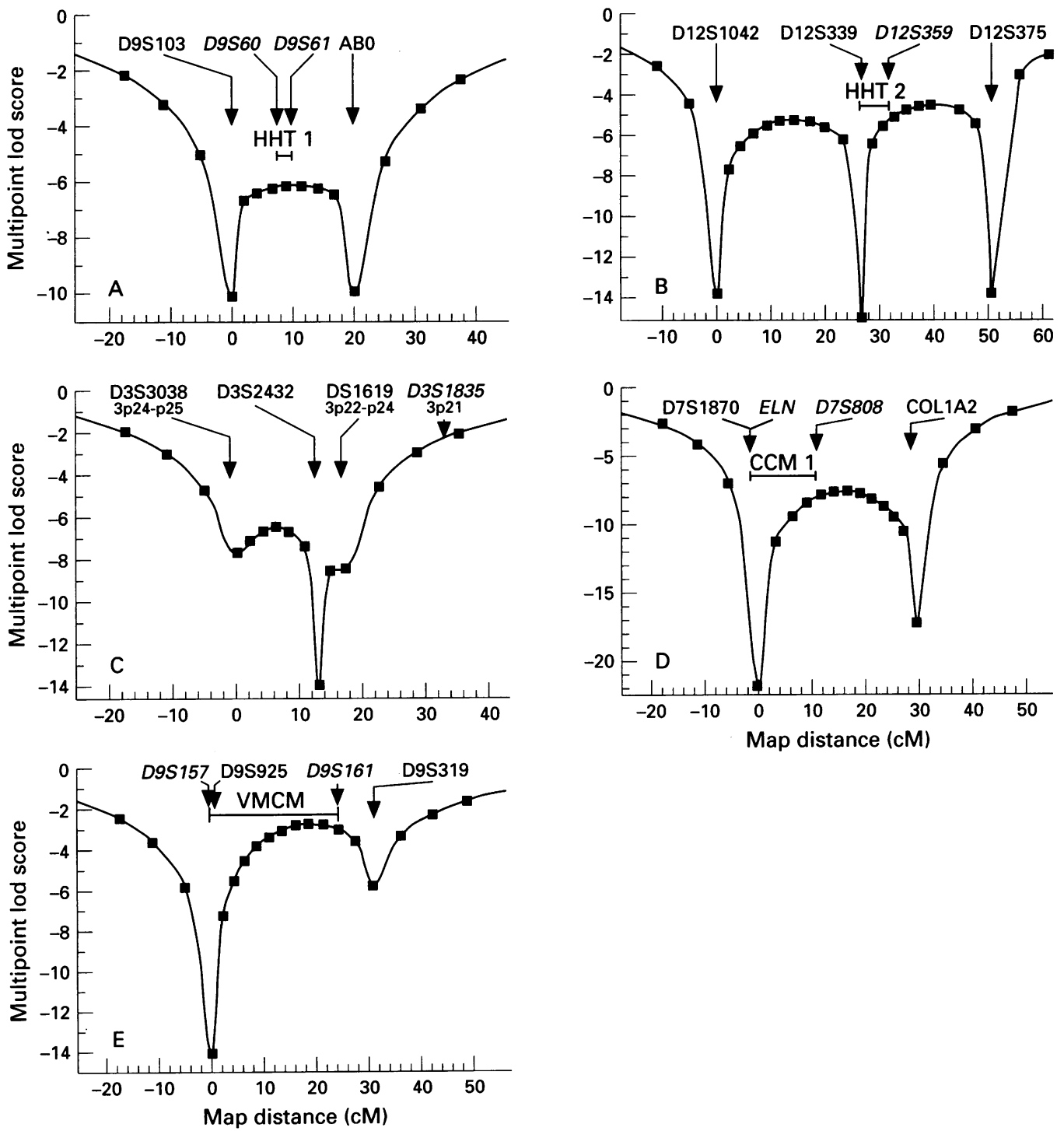

Figure 2 Multipoint linkage analysis plots for disease locus HHT versus marker loci. Candidate regions are represented Figure 2 Multipoint linkage analysis plots for disease locus Horted family. $(A) A B O$ and D9S103 (MFD77) exclude locus by the solid bars. Loci in italics were not scored in the reported family. (A) ABO and D9S (B) D12S1042 (CHLC.ATA27A06), D12S339 (AFM294wc5), and D12S375 (CHLC.GATA3F02) exclude HHT2; (C) D3S3038 (CHLC.GATA73D01), D3S2432 (CHLC.GATA27C08), and D3S1619 (AFM350tf1) exclude the chromosome 3p22 region; (D) D7S1870 (AFMa060xc9) and COL1A2 exclude CCM1; (E) D9S925 (CHLC.GATA27A11) and D9S319 (CHLC.GATA12C06) exclude VMCM. 
laid with $10 \mu \mathrm{l}$ of mineral oil, denatured at $96^{\circ} \mathrm{C}$ for five minutes, and processed for 30 cycles $\left(94^{\circ} \mathrm{C}\right.$ for 40 seconds, $57^{\circ} \mathrm{C}$ for $40 \mathrm{sec}-$ onds, $72^{\circ} \mathrm{C}$ for 40 seconds), followed by a final extension step at $72^{\circ} \mathrm{C}$ for five minutes. Reaction volume was mixed with $10 \mu \mathrm{l}$ formamide, denatured at $96^{\circ} \mathrm{C}$ for five minutes, and 5 to $7 \mu \mathrm{l}$ of the mix were loaded on a $6 \%$ polyacrylamide sequencing gel. PCR products were detected by exposing dried gels to $x$ ray films. Primer sequences are reported in GDB (Johns Hopkins University, Baltimore, USA). Multipoint linkage analysis was performed by the computer program package FASTLINK, ${ }^{17}$ assuming equal sex recombination fractions and a frequency of 0.0001 for the allele causing the HHT phenotype. Marker allele frequencies were estimated from the family itself. A reduced age dependent penetrance was used (penetrance $0.16,0.41,0.57,0.74,0.90$, and 0.97 at age class $<20,21-30,31-40,41-50,51-60$, and $>60$ years respectively). Affection status was scored as unknown in at risk subjects with fewer than five cutaneous or mucous telangiectases or fewer than 10 episodes of epistaxis per year.

The order of loci and the genetic distances between adjacent loci were taken from published $^{18}$ and online ${ }^{19}$ data. Estimated recombination fractions were converted to centimorgans (cM) using the Haldane mapping function.

\section{Results and discussion}

Multipoint linkage analysis results are shown in fig 2. Two point linkage analysis with the same markers was not significantly affected using a wide range of penetrance values and allele frequencies, even using a low penetrance model (data not shown).

The HHT1 locus has been mapped in the $2 \mathrm{cM}$ interval between markers D9S60 and D9S61. ${ }^{7}$ Markers D9S103 and ABO flanking the interval exclude the whole region (fig $2 \mathrm{~A}$ ).

The candidate interval containing the HHT2 locus is flanked by markers D12S339 and D12S345. ${ }^{8} \mathrm{~A}$ much larger interval has been excluded in this family (fig $2 \mathrm{~B}$ ).

Markers D3S3038, D3S2432, and D3S1619 exclude a region of about $50 \mathrm{cM}$ including $3 \mathrm{p} 22$, and thus exclude the TGF- $\beta$ receptor type II as a candidate gene (fig 2C). The regions where CCM1 and VMCM had been mapped were also excluded (fig $2 \mathrm{D}, \mathrm{E}$ ).

Our data indicate the existence of at least a third HHT locus. The high proportion of liver involvement found in our family is quite uncommon in HHT, and was reported in only $8 \%$ of HHT patients in a large series. ${ }^{20}$ We speculate that the high frequency of liver vascular anomalies is the hallmark of a distinct subtype of HHT. Clinical heterogeneity is in agreement with the genetic heterogeneity shown.

We have no explanation for the evident sex bias in liver involvement, but it may just be coincidental since in other families ${ }^{2122}$ a male predominance has been reported.

Since no TGF- $\beta$ binding protein genes other than endoglin and TGF- $\beta$ receptor type II have been mapped, a systematic linkage mapping search is at the moment the only possible approach and is in progress.

The financial support of Telethon-Italy (grant No E.312) is gratefully acknowledged. We wish to thank Professor G Novelli for his gift of D7S1870 PCR primers and Professor M Fraccaro for helpful discussion.

1 Online Mendelian Inheritance in Man, OMIM. The human genome data base project. Baltimore: Johns Hopkins University, MIM 187300, date last edited November 1995.

2 McDonald MT, Papenberg KA, Ghosh S, et al. A disease locus for hereditary hemorrhagic telangiectasia maps to chromosome 9q33-34. Nature Genet 1994;6:197-204.

3 Shovlin CL, Huges JMB, Tuddenham EGD, et al. A gene for hereditary haemorrhagic telangiectasia maps to chrofor hereditary haemorrhagic telangiectasia
mosome 9q3. Nature Genet 1994;8:205-9.

4 McAllister KA, Grogg KM, Johnson DW, et al. Endoglin a TGF- $\beta$ binding protein of endothelial cells, is the gene for hereditary haemorrhagic telangiectasia type 1. Nature Genet 1994;6:345-51.

5 Porteous MEM, Curtis A, Williams O, Marchuk D, Bhattacharya SS, Burn J. Genetic heterogeneity in hereditary haemorrhagic telangiectasia. F Med Genet 1994;31:925-6.

6 McAllister KA, Lennon F, Bowles-Biesecker B, et al. Genetic heterogeneity in hereditary haemorrhagic telangiectasia: possible correlation with clinical phenotype. $\mathcal{F}$ Med Genet 1994;31:927-32.

7 Heutink P, Haitjema T, Breedveld GJ, et al. Linkage of hereditary haemorrhagic telangiectasia to chromosome $9 \mathrm{q} 34$ and evidence for locus heterogeneity. $7 \mathrm{Med}$ Genet 1994;31:933-6.

8 Vincent $P$, Plauchu $H$, Hazan J, Faure S, Weissenbach J, Godet J. A third locus for hereditary haemorrhagic $\mathrm{J}$, Godet $\mathrm{J}$. A third locus for hereditary haemorrhagic
telangiectasia maps to chromosome 12q. Hum Molec Genet telangiectasia

9 Johnson DW, Berg JN, Gallione CJ, et al. A second locus for hereditary hemorrhagic telangiectasia maps to chromosome 12. Genome Res 1995;5:21-8.

10 Online Mendelian Inheritance in Man, OMIM. The human genome data base project. Baltimore: Johns Hopkins University, MIM 600376, date last edited November 1995.

11 Gunel M, Awad IA, Anson J, Lifton RP. Mapping a gen causing cerebral cavernous malformation to $7 \mathrm{q} 11.2-\mathrm{q} 21$. Proc Natl Acad Sci USA 1995;92:6620-4.

12 Dubovsky J, Zabramski JM, Kurth J, et al. A gene responsible for cavernous malformations of the brain maps to chromosome 7q. Hum Molec Genet 1995;4:453-8.

13 Marchuk DA, Gallione CJ, Morrison LA, et al. A locus for cerebral cavernous malformations maps to chromosome cerebral cavernous malformations maps to chro

14 Boon LM, Mulliken JB, Vikkula M, et al. Assignment of a locus for dominantly inherited venous malformations to chromosome 9p. Hum Molec Genet 1994;3:1583-7.

15 Gallione CJ, Pasyk KA, Boon LM, et al. A gene for familia venous malformations maps to chromosome $9 p$ in a second large kindred. $\mathcal{F}$ Med Genet 1995;32:197-9.

16 Buscarini E, Buscarini L, Civardi G, Arruzzoli S, Bossalini $G$, Piantanida $M$. Hepatic vascular malformations in her-

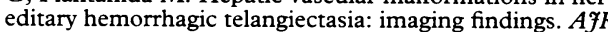
1994;163:1105-10

17 Shaffer AA, Gupta SK, Shriram K, Cottingham RW. Avoiding recomputation in linkage analysis. Hum Hered 1994; 44:225-37.

18 Povey S, Armour J, Farndon P, et al. Report on the third international workshop on chromosome 9. Ann Hum Genet international work

19 Dubovsky J, Sheffield VC, Duyk GM, Weber GL. Set of short tandem repeat polymorphism for efficient linkage screening of the human genome. Hum Molec Genet 1995 4:449-52.

20 Plauchu H, de Chadarévian JP, Bideau A, Robert JM. Agerelated clinical profile of hereditary hemorrhagic telangiectasia in an epidemiologically recruited population. Am $\mathcal{F}$ Med Genet 1989;32:291-7.

21 Nikolopoulos N, Xynos E, Vassilakis JS. Familial occurrence of hyperdynamic circulation status due to intrahepatic fistulae in hereditary hemorrhagic telangiectasia. Hepatogastroenterology 1988;35:167-8.

22 Guillen B, Guizar J, de la Cruz J, Salamanca F. Hereditary hemorrhagic telangiectasia: report of 15 affected cases in a Mexican family. Clin Genet 1991;39:214-8. 